\title{
A EDUCAÇÃO ESCOLAR COMO UM BOM NEGÓCIO
}

\author{
Luiz Carlos Barreira $^{1}$ \\ Universidade Católica de Santos - UniSantos
}

\section{RESUMO}

Este trabalho focaliza a atuação política e empresarial de António Figueirinhas, o qual foi um dos principais representantes do professorado primário nas primeiras décadas da república portuguesa, sobretudo por ter defendido os interesses de classe da categoria profissional à qual pertencia. Figueirinhas fez da imprensa de educação e ensino uma das principais trincheiras dos professores na luta por seus interesses de classe. Assim procedendo, fez confluir os interesses pedagógicos dos professores primários para os seus interesses comerciais. Foi autor de livros escolares, editor, livreiro, proprietário de escolas, jornais e revistas e de uma fábrica de móveis escolares. Foi, portanto, um insofismável empresário no campo da educação escolar.

Palavras-chave: Educação como Negócio; António Figueirinhas (1865-1945); Imprensa de Educação e Ensino; O Meu Jornal (Porto, 1915-1917).

\section{SCHOOL EDUCATION AS A GOOD DEAL}

\section{ABSTRACT}

This paper focuses on the political and business activities of António Figueirinhas, who was one of the main representatives of the primary teachers in the first decades of the Portuguese republic, especially in support of the class interests of the profession at which he belonged. Figueirinhas used the press of education and teaching as one of the most important primary teachers' trench in the fighting by their class interests. In doing so, he did converge the pedagogic interests of the primary teachers to his commercial interests. He was author of books, editor, bookseller, proprietor of educational establishments, newspapers and journals and also proprietor of a school furniture factory. Unmistakably, he was a businessman in the educational area.

Keywords: Education as a business; António Figueirinhas (1865-1945); Press of education and teaching; O Meu Jornal (Porto, 1915-1917).

\section{Introdução ${ }^{2}$}

A educação era um "bom negócio" em Portugal nos primeiros anos de implantação da República, proclamada a 5 de outubro de 1910. António Figueirinhas, proprietário, editor e diretor do jornal O Meu Jornal, semanário editado na cidade do Porto entre 1915 e 1917, é um personagem emblemático desse "bom negócio". Professor do ensino primário, Figueirinhas foi autor de livros escolares e durante muitos anos, antes de criar o seu próprio jornal, havia trabalhado como colaborador em vários periódicos, dentre os quais a revista Educação Nacional se destaca ${ }^{3}$. Quando o "seu" jornal veio a público, uma das críticas que recebeu foi a de que ele seria usado tão somente para defender os interesses do seu diretor, editor e proprietário. Embora negasse peremptoriamente tais críticas, Figueirinhas reservou a quarta página do "seu" jornal para "anúncios e reclamos", na qual 
notificava a publicação de livros escolares de sua autoria e de outros educadores, todos eles, entretanto, editados em sua própria editora, impressos em uma tipografia de sua propriedade e comercializados por sua livraria. Sim! O senhor António Figueirinhas, além do "seu" jornal, também possuía uma editora, uma tipografia e uma livraria. Mas o rol de suas propriedades, vinculadas ao campo da educação escolar, não se encerrava com essas últimas. Era também proprietário de uma fábrica de móveis escolares e, muito provavelmente, também de um internato feminino. Indubitavelmente, estamos diante de um empresário que fez da educação um autêntico e promissor negócio. Que nós saibamos, não houve, no limiar da República brasileira, figura semelhante a Figueirinhas. Talvez essa tenha sido a principal razão que nos fez atentar à experiência empresarial de Figueirinhas no campo da educação escolar, quando manuseávamos uma coleção completa do "seu" jornal na hemeroteca da Biblioteca Nacional, em Lisboa ${ }^{4}$.

Antes, porém, de apresentarmos e problematizarmos as iniciativas empresariais de António Figueirinhas e o uso que esse educador fez da imprensa de educação e ensino, tendo em vista conciliar os seus interesses comerciais com os interesses pedagógicos dos professores primários portugueses na primeira metade do século $\mathrm{XX}$, consideramos necessário discorrer, ainda que de forma sucinta, sobre o contexto em que se inserem tais iniciativas. Para tanto, recorreremos à produção historiográfica portuguesa sobre educação escolar, com destaque especial para alguns estudos recentes sobre alfabetização e escolarização no período estudado, bem como a estudos igualmente recentes sobre a imprensa de educação e ensino naquele país. Entretanto, o lastro principal da investigação do tema central deste trabalho (as iniciativas empresariais de Figueirinhas no campo da educação escolar) está na análise que fizemos do periódico O Meu Jornal e nos estudos recentes sobre ele e sobre a equipe responsável por sua edição.

\section{Alfabetização e Escolarização em Portugal na Virada do Século XX}

Um manifesto em prol da instrução popular e em defesa do professorado primário, lançado na cidade do Porto, em 1897, no âmbito das atividades de um congresso que reuniu o professorado primário português, denunciava "o vergonhoso déficit intelectual do país: cinco milhões de portugueses / quatro milhões de analfabetos" (NÓVOA; BANDEIRA, 2003); ou seja, 80 por cento da população portuguesa não sabia ler e escrever, no apagar das luzes dos oitocentos. Iniciava-se, então, a luta contra o analfabetismo, bandeira de "uma geração que tentaria mudar os rumos da educação em Portugal.” (NÓVOA; BANDEIRA, 2003).

Na prática discursiva dos ideólogos da Primeira República portuguesa (1910-1926), a educação escolar (ainda que mínima) para todos era concebida como um direito do cidadão e um dever do Estado republicano. Porém, a massificação do ensino, em Portugal, foi um processo bastante perceptível apenas a partir de meados do século XX, de acordo com a recente historiografia portuguesa sobre o assunto (FERNANDES, 2003; MAGALHÃES, 2003; PINTASSILGO; MOGARRO, 2003; TEODORO, 2003). Entretanto, essa mesma historiografia considera a transição do século XIX para o XX um momento decisivo do processo de construção da "escola de massas" em Portugal. Nesse momento, e ao longo de toda a Primeira República, a escola teria assumido "uma grande centralidade no quadro do projeto de homogeneização cultural dirigido pela elite política e intelectual da época e centrado na ideia de Estado-nação." (PINTASSILGO; MOGARRO, 2003, p. 52). Os efeitos dessa política educativa, tímida e elitista, podem ser observados, 
por exemplo, nos estudos realizados por Teodoro (2003). Segundo esse estudioso, em meados do século XX, Portugal apresentava uma taxa de analfabetismo estimada em 45 por cento da população com idade superior a 12 anos (TEODORO, 2003, p. 38). Ainda que significativos, pois em fins do século XIX a taxa de analfabetismo girava em torno de 80 por cento, os resultados então alcançados por Portugal, segundo essa mesma fonte, ainda estavam muito aquém daqueles alcançados por outras regiões europeias, que apresentavam, então, as seguintes taxas de analfabetismo: Europa do Norte, 1,25 por cento; Europa Ocidental, 2,5 por cento; Europa do Leste; 8 por cento; Europa do Sul, 19 por cento. Enquanto o índice de analfabetismo na Europa girava, em média, em torno dos 8 por cento, em Portugal esse índice era de 45 por cento.

Outro dado, aqui considerado por corroborar a tese segundo a qual a escola de massas, em Portugal, passou por um processo decisivo na virada do século XX e ao longo da primeira metade desse século, pode ser buscado no cotejo dos seguintes censos populacionais: o Censo da População do Reino de Portugal, realizado a $1^{\circ}$ de dezembro de 1900, e o IX Recenseamento Geral da População de Portugal, realizado a 15 de dezembro de 1950, pelo Instituto Nacional de Estatística.

No Censo de 1900, o percentual da população que declarava saber ler é bastante discreto: apenas 27 por cento. A considerar o conjunto da população com idade superior a 10 anos, o percentual da população masculina considerada alfabetizada não ultrapassava 36 por cento; o dobro, entretanto, do percentual verificado em relação à população feminina alfabetizada. Vale lembrar que, nesse período, a população feminina situada nessa faixa etária era numericamente superior à masculina (CANDEIAS, 2004, p. 108-113).

O recenseamento de 1950, por sua vez, evidencia aspectos bastante interessantes sobre o processo de expansão da escola de massas em Portugal. O percentual da população que declarava saber ler saltou de 27 para 58 por cento. Esse mesmo avanço também se verificou em relação à população masculina alfabetizada, com idade superior a 10 anos; esse segmento da população portuguesa saltou de 36 para 67 por cento. $\mathrm{O}$ avanço mais significativo ocorreu, entretanto, em relação à população feminina alfabetizada, situada nessa mesma faixa etária; esse segmento da população portuguesa saltou de 18 para 51 por cento. Entretanto, passados cinquenta anos, as distâncias entre homens e mulheres, no que diz respeito à alfabetização, ainda permaneciam (CANDEIAS, 2004, p. 169-178).

António Figueirinhas e seus empreendimentos educacionais inserem-se no contexto acima delineado. Figueirinhas é um dos representantes da geração que tentou mudar os rumos da educação em Portugal. É preciso advertir, entretanto, que a categoria "geração" não se faz condição necessária e suficiente para compreendermos os sentidos que os atores desse processo histórico atribuíram às próprias práticas. Evidentemente, nem todos que pertenceram à geração de Figueirinhas atribuíram à educação escolar os mesmos sentidos, significados. Nem todos fizeram uso da educação escolar, tendo em vista os mesmos objetivos (políticos, ideológicos, materiais). Nossa hipótese é que esse intelectual da educação teria participado da luta contra o analfabetismo em Portugal, da escolarização em particular, com interesses bastante claros e definidos. Ao que tudo indica, ter-se-ia valido da popularidade que gozava junto ao professorado primário português para se inserir e se firmar na sociedade de então como um empresário da educação escolar, mesmo que ainda não tivesse plena consciência desses seus atos. Nesse sentido, corroboramos uma das principais teses de Edward Palmer Thompson (1981), segundo a qual os processos de aquisição de consciência são produtos das lutas que os sujeitos travam ao longo de suas existências, tendo em vista suprir suas necessidades. Assim, a consciência (de classe, por 
exemplo) não antecede as lutas (de classe, de acordo com o exemplo), mas é forjada no calor da própria luta. António Figueirinhas fez-se um empresário da educação nas relações que estabeleceu com aliados e adversários nas "lutas de representações" das quais participou ativamente, com vistas, talvez, não à erradicação do analfabetismo em Portugal, mas à expansão das práticas de escolarização nesse país na primeira metade do século XX.

Muitas são as facetas desse singular intelectual da educação escolar que poderiam ser aqui exploradas. Além dos apontamentos biográficos de praxe, interessa-nos, à luz dos objetivos visados neste trabalho, destacar as seguintes facetas: sua presença no movimento associativo de professores da educação primária; sua atuação na imprensa de educação e ensino; sua participação no mercado editorial; e, por fim, sua condição de proprietário de estabelecimentos de ensino e de fábricas de móveis escolares.

\section{Figueirinhas e o Movimento Associativo Docente}

António Simões Figueirinhas nasceu em Vouzelas em 1865 (não se tem o registro do dia e do mês do nascimento) e faleceu na cidade do Porto no dia 6 de julho de 1945. Filho de lavradores abastados, cursou Teologia no Seminário de Viseu, mas não chegou a se ordenar. Em 1885, habilitou-se para o magistério primário e começou a exercer a profissão docente em Oliveira de Frades. Três anos depois, em 1888, fundou nessa cidade o Colégio Viriato, cuja sede foi transferida para Viseu, entre 1894 e 1895. Em Viseu, lecionou no Liceu da cidade por um breve período. Em 1986, transferiu sua residência para a cidade do Porto, onde se fixou definitivamente. Lecionou francês, inglês e alemão em muitas escolas, principalmente no Colégio de Santa Marta. Atuou no campo jornalístico desde muito cedo. Criou vários periódicos, como O Lafões, O Porto e O Meu Jornal, e foi colaborador em outros tantos. Fez-se conhecer nesse campo graças à sua atuação no semanário Educação Nacional e, principalmente, por ter defendido os interesses de classe do professorado primário português (NÓVOA; BANDEIRA, 2003). Desse periódico, que começou a circular em 04 de outubro de 1896, e que foi editado por quase um século, foi administrador e diretor desde o seu surgimento, sendo considerado o principal dinamizador e protagonista do seu projeto original ${ }^{6}$.

António Figueirinhas fez-se um dos principais representante de parte do professorado primário português, sobretudo por ter defendido os interesses de classe da categoria profissional a qual pertencia. Categoria que se fazia cada vez mais necessária à sociedade portuguesa de então, frente aos desafios trazidos pelas lufadas de vento de modernidade que a ela chegavam, oriundas, principalmente, da Europa Ocidental e do Norte. Uma categoria dividida, entretanto, por duas forças políticas: uma conservadora, outra progressista. Os "Grupos do Norte", como eram conhecidos os movimentos associativos do Norte de Portugal, onde Figueirinhas atuava, caracterizavam-se por práticas e posições marcadamente católicas e conservadoras. Outros movimentos, como os de Lisboa, orquestrados por lideranças como as de César Porto ${ }^{7}$ e Adolfo Lima ${ }^{8}$, entre outros, contrapunham-se aos movimentos do norte do país por suas práticas e posições, consideradas mais progressistas.

Figueirinhas fez da imprensa (de educação e ensino) uma das principais trincheiras dos professores na luta por seus interesses de classe. A revista Educação Nacional foi uma delas. Na edição de 10 de janeiro de 1906 desse periódico (cerca de cinco anos antes da proclamação da República portuguesa), Figueirinhas fez a seguinte declaração: 
O professor, dia-a-dia, pela sobrecarga constante de deveres e pela forçada miséria material, se afirma um mártir heróico, que morre no reduto, esgotado aos primeiros ataques da ignorância e da rotina. Junca-se a gleba de cadáveres de professores primários ignorados, como alguns campos de batalha dos de soldados obscuros, à voz de conquistadores desdenhosos. Não é um sacerdócio: é um suicídio. Não é uma dedicação: é uma abdicação dos direitos mais rudimentares da existência. (EDUCAÇÃO NACIONAL, Porto, 10 jan. 1904, apud NÓVOA; BANDEIRA, 2003).

Por defender uma política (agressiva) de defesa do professorado primário português, parte significativa desse segmento do magistério passou a legitimar praticamente todas as ações encetadas por Figueirinhas no campo da educação escolar. $\mathrm{O}$ principal objetivo de tal política era tornar a docência uma profissão minimamente digna. Para a consecução desse objetivo, não seria suficiente apenas denunciar o descalabro e a penúria do ensino primário, e reivindicar melhorias salariais e de vida para o professorado primário. Seria preciso mais. Seria preciso promover congressos pedagógicos e liderar o professorado, organizando-o em associações docentes que ultrapassassem os limites das sociedades de socorro mútuo criadas em fins do século XIX. Foi nesse contexto e com esse intuito que a Liga Nacional do Professorado Primário foi criada em 1907.

\section{Figueirinhas e a Imprensa de Educação e Ensino}

Dentre os vários periódicos em que António Figueirinhas atuou, seja como editor e diretor, seja como colaborador, as fontes consultadas destacam os seguintes: Arquivo Escolar, Boletim Pedagógico, Educação, A Escola Primária, O Hermínio, A Instrução, O Meu Jornal, Português Popular, Revista dos Liceus e A Tribuna (NÓVOA; BANDEIRA, 2003). De todos eles, O Meu Jornal foi aquele que mais chamou nossa atenção, sobretudo pelas evidências que nele encontramos sobre as iniciativas empreendedoras de Figueirinhas no campo da educação escolar.

O Meu Jornal circulou semanal e ininterruptamente de 17 de outubro de 1915 a 22 de julho de 1917. Figueirinhas foi seu diretor, editor e proprietário. Eusébio de Queirós ${ }^{9}$ respondeu pela Redação do jornal. Ao lado deles, dois outros intelectuais, Rodrigues dos Santos $^{10}$ e José Queirós ${ }^{11}$, constituíam o núcleo responsável pela edição do jornal, pelo menos até agosto de 1916, quando a função de administrador foi criada e Juliano Pereira ${ }^{12}$ foi convidado para a exercer, integrando-se, assim, ao grupo gestor inicial do jornal. Em abril de 1917, Juliano Pereira foi substituído por Domingos de Sousa ${ }^{13}$ no exercício da função, que a exerceu até a publicação do último número do jornal. Não se tem registro das razões que levaram à suspensão da publicação de $\mathrm{O}$ Meu Jornal. Entretanto, como dito anteriormente, Figueirinhas voltaria ao clube dos proprietários de periódicos em 1927, readquirindo e dirigindo a revista Educação Nacional.

$\mathrm{O}$ grupo gestor de $\mathrm{O}$ Meu Jornal assinava a maioria dos artigos publicados nesse jornal. Alguns professores, como Hermínio Andrade ${ }^{14}$, João Paulo Freire ${ }^{15}$ e Manuel de $\mathrm{Melo}^{16}$, entre outros, contribuíram, entretanto, como colaboradores eventuais. Quanto à sua diagramação, era um impresso composto por apenas quatro páginas, com as seguintes dimensões: $49 \mathrm{~cm}$ x $54 \mathrm{~cm}$. Cada página correspondia a uma seção e eram assim denominadas: "Página Doutrinária" ( $1^{\mathrm{a}}$ página), "Página de Combate" (2 página), "Página Literária e de Informação" (3 página) e "Página de Anúncios e Reclamos" (4 página). 
Os temas abordados em O Meu Jornal foram muitos e diversificados. Dentre eles, António Nóvoa (1993, referência 361) destaca os seguintes:

- A reorganização das escolas normais e a deficiente qualidade do ensino e dos programas.

- A missão do educador (zelo, pontualidade e comportamento moral).

- As ações do Sindicato dos Professores Primários de Portugal.

- Qualificação do corpo docente: professores das aldeias versus professores das cidades: arbitrariedades dos inspetores.

- O papel social do Montepio.

- Os livros escolares e o papel do livro de leitura no ensino primário;

- A importância dos cursos noturnos e das escolas móveis no combate ao analfabetismo.

- A educação da mulher: o seu papel no lar, a maternidade e a influência da família na escola.

- A situação (precária) dos edifícios escolares e a necessidade de uma construção programada.

- Os métodos educativos (intuitivo, individual, mútuo), os programas escolares e a introdução de novas matérias no currículo (educação física, educação moral e cívica etc.).

- Exames, avaliação, competência profissional e arte de interrogar.

- Castigos corporais (plebiscito sobre o uso da palmatória).

- Diferenças entre ensino neutro e ensino religioso.

- A indiferença política para com a instrução e as consequências sociais e culturais desse fato.

Dos temas destacados por Nóvoa, alguns deles chamam a atenção, sobretudo por anteciparem algumas das iniciativas comerciais de Figueirinhas. A título de ilustração, frisaria os seguintes: "Os livros escolares e o papel do livro de leitura no ensino primário" (a propósito dos livros escolares editados e comercializados pela Casa Editora e Livraria Figueirinhas) e "A educação da mulher, o seu papel no lar, a maternidade e a influência da família na escola" (a propósito de um internato para meninas que a família Figueirinhas abriria na cidade do Porto).

Apesar de ter colaborado com vários outros periódicos - dirigindo e editando alguns deles, inclusive -, Figueirinhas decidiu criar seu próprio jornal. Por qual razão? Ele mesmo esclarece o motivo que o levou a isso em uma nota intitulada "O Programa de $\mathrm{O}$ Meu Jornal" (O MEU JORNAL, Porto, p. 2-3, 17 out. 1915). Nessa nota, apresenta as seções do jornal e os conteúdos que seriam abordados em cada uma delas. Posto isso, recupera sua trajetória no jornalismo especializado em educação, discorre sobre mazelas vividas nesse meio, rememora seus fortes vínculos com o professorado primário e suas lutas e, por fim, justifica a criação do "seu" jornal. Em dois momentos dessa nota, justifica o seu retorno à imprensa, associando-o aos fortes vínculos que sempre tivera com o professorado primário português e ao fato de não ter encontrado espaço em outros periódicos da imprensa especializada para divulgar livros de sua autoria e livros de outros educadores, editados e comercializados por ele.

Pode-se afirmar, portanto, que o retorno de António Figueirinhas ao jornalismo, criando seu próprio jornal, deveu-se, básica e principalmente, ao fato de ele não ter encontrado espaço em outros periódicos para a divulgação dos livros escolares que 
comercializava, fossem eles de sua autoria ou não, como evidenciado no trecho a seguir, apesar dos senões.

O Meu Jornal não é, pois, um jornal, como mal-intencionados insinuaram, uma tabuleta [tablóide] para anúncios de livros da Livraria Figueirinhas. É evidente que todos os jornais do mundo e todas as revistas anunciam e reclamam as obras próprias e alheias, sem que os espíritos fúteis discutam um fato tão singelo e tão inocente. (O MEU JORNAL, Porto, p. 3, 17 out. 1915).

O "fato tão singelo e tão inocente" de anunciar livros de sua autoria, assim como livros de terceiros editados e comercializados por ele, em um jornal de sua propriedade, talvez tenha sido a razão principal para o surgimento de $\mathrm{O}$ Meu Jornal. Por intermédio dele, ainda que por pouco tempo (cerca de dois anos), Figueirinhas fez confluir os interesses pedagógicos dos professores primários para os seus interesses comerciais.

\section{Figueirinhas e o Mercado Editorial}

Os livros de autoria de António Figueirinhas não eram "particularmente originais, nem do ponto de vista metodológico nem quanto à sua apresentação", segundo estudiosos do assunto (NÓVOA; BANDEIRA, 2003). Mas esses livros, segundo esses mesmos estudiosos, conseguiram "uma grande difusão junto do professorado, constituindo, em diversos períodos, os livros mais utilizados nas escolas primárias." (NÓVOA; BANDEIRA, 2003). Por essa razão, Figueirinhas e seus livros teriam exercido significativa influência sobre o professorado português ao longo da primeira década do século XX.

Além de autor, António Figueirinhas foi, como já sabido, editor e livreiro. A Casa Editora (e Livraria) A. Figueirinhas, que mais tarde teve seu nome alterado para Empresa (e Livraria) da Educação Nacional, era propriedade sua. Nela, esse ilustre homem das letras e dos negócios no campo da educação escolar publicou parte significativa dos livros escolares de sua autoria, como informado por Nóvoa e Bandeira (2003). Por ano de edição e em ordem cronológica crescente, esses livros foram os seguintes:

- 1901: Contos para as Crianças

- 1915: Geografia: Resumo para Escolas Normais e Liceus

- 1915: Livro de Leitura para a $1^{a}$ Classe

- 1915: Manuscritos

- 1916: O Livro da Festa da Árvore

- 1916: Almanaque Figueirinhas: para Professores e Amigos da Instrução

- 1916: Moral e Educação Cívica: $2^{a}, 3^{\mathrm{a}}$ e $4^{\mathrm{a}}$ Classes do Ensino Primário Elementar

- 1917: Curso Abreviado de Literatura

- 1917: A, B, C do Estilo e da Composição

- 1918: Verdades como Punhos - Aos Professores

- 1920: Gramática Francesa

- 1920: Gramática Inglesa

- 1922: História Pátria

- 1922: A Civilidade - Para Crianças e Jovens

- 1923: Gramática Portuguesa

- 1929: Impressões sobre a Instrução no Rio de Janeiro e São Paulo

- 1930: O Último Concurso de Livros Primários

- 1931: Carta Aberta ao Exmo. Sr. Ministro da Instrução 
- 1935: Aritmética: Para Todas as Classes, Aprovada Oficialmente

- 1937: Ciências Naturais: $4^{a}$ classe

- 1938: Geometria: $3^{\mathrm{a}}$ e $4^{\mathrm{a}}$ classes

- 1948: Guia de Desenho

- 1950: Como se Aprende a Ler

- 1950: Tabuada das Escolas

- S/D: A Nossa Instrução Primária e o Senhor Dr. Alfredo Magalhães: Breve Crítica ao Desgraçado Ensino Público (NÓVOA; BANDEIRA, 2003).

Não foram poucos os anúncios de livros, livrarias, papelarias, lojas de venda de móveis e materiais escolares publicados na quarta página do semanário pedagógico $\mathrm{O}$ Meu Jornal, especialmente dedicada aos "anúncios e reclamos". Um desses "anúncios e reclamos", entretanto, destaca-se por se fazer presente em praticamente todas as edições do jornal. Trata-se de um anúncio sobre o Almanaque Figueirinhas, que reunia uma série de livros escolares de autoria do próprio Figueirinhas. Os títulos dessa série são os seguintes:

- Primeiro Livro de Leitura

- Segundo Livro de Leitura

- Educação Cívica

- Gramática Portuguesa

- Corografia

- Agricultura

- Ciências Naturais

- História Pátria

- Aritmética

- Moral

- Manuscrito

- Tabuada das Escolas

- Cadernos de Escrita

- Cadernos de Aritmética - $1^{\circ}$ (O MEU JORNAL, Porto, p. 4, 17 out. 1915).

A propósito dessa série de livros escolares, vale lembrar uma nota bastante significativa, sobretudo por seu apelo mercadológico, publicada pela Redação do jornal, em 17 de outubro de 1915, e intitulada "Ao professorado do país". Nessa nota, António Figueirinhas roga a todos os professores que adotem a Série Escolar Figueirinhas. Informa, ainda, que a Livraria A. Figueirinha não enviaria aos professores os livros que muitos deles haviam solicitado, por terem sido editados por outras editoras, que não a Casa Editora A. Figueirinhas. Justifica o procedimento apresentando uma denúncia, qual seja a de que as editoras dos livros solicitados estavam boicotando as iniciativas de Figueirinhas na área editorial. Em represália, a Livraria A. Figueirinhas enviaria aos professores apenas livros editados pela Casa Editora A. Figueirinhas.

Além dos livros de sua autoria, Figueirinhas publicou e comercializou livros de outros autores, como, por exemplo, os que seguem:

- Cartilha Portuguesa, por A. Justino Ferreira (Inspetor Escolar).

- A, B, C Ilustrado, por A. Campos.

- O Meu Livro, por José Agostinho.

- Exercícios de Estilo para as Escolas Primárias (temas de redação e composição), por Manuel de Melo.

- Civilidade, por José Agostinho.

Um episódio ocorrido em 1930 evidencia aspectos particularmente importantes 
sobre o lugar social (político, ideológico, institucional, cultural) de onde Figueirinhas falava. Esse episódio, de acordo com informações reunidas por Nóvoa e Bandeira (2003) em notas que escreveram sobre o assunto, refere-se a uma polêmica, que Figueirinhas tornou pública, sobre o processo de elaboração das listas de livros escolares aprovados pelo Ministério Público português, o qual tinha por objetivo orientar o professor primário na escolha dos livros escolares que ele adotaria na sua prática docente. Episódio ocorrido antes, portanto, de Portugal adotar a política de imposição de um livro único. Adolfo Lima era um dos vogais da comissão constituída pelo governo português para examinar os livros escolares editados em Portugal e elaborar a lista dos "livros aprovados". Ao que tudo indica os livros editados por Figueirinhas não devem ter passado pelo crivo da referida comissão. Em resposta a essa exclusão, Figueirinhas publicou dois opúsculos: O Último Concurso de Livros Primários (1930) e Carta Aberta ao Exmo. Sr. Ministro da Instrução (1931). Com eles, objetivava atingir um dos seus principais alvos, Adolfo Lima. Nesses opúsculos, na avaliação de Nóvoa e Bandeira (2003):

António Figueirinhas procura ridicularizar os escritos de Adolfo Lima, aproveitando para criticar violentamente os conceitos que tinham dado corpo a uma parte importante da pedagogia portuguesa: ensino laico, escola racional, educação integral, escola única etc. A sua reação revela, de forma radical, a separação entre correntes do professorado que até aí tinham conseguido coabitar, ainda que numa tensão conflituosa.

Apesar de inserida no contexto dessa polêmica, a forma como Figueirinhas se expressou sobre o assunto e, principalmente, o conteúdo dessa expressão evidenciam aspectos da sua visão de mundo. Segundo ele:

Coisa singular, a nós parece-nos que há duas ditaduras com finalidade definida e com orientação positiva - a da Itália, com Mussolini; a da Rússia, com Stálin. Estas sabem para onde vão. Têm um programa, têm princípios definidos e dentro deles agem. Uma é da extrema esquerda, outra da extrema direita. Nós nelas admiramos apenas a coerência, sem hipocrisias. Formam escolas, e as gerações nos seus princípios são educadas. A escola da Itália deslumbra-nos; a da Rússia aterra-nos. (EDUCAÇÃO NACIONAL, Porto, 11 jan. 1931, apud NÓVOA; BANDEIRA, 2003).

Em um importante momento da história política de Portugal - período de transição da Primeira República para o Estado Novo, entre meados da década de 1920 e meados da década de 1930 -, Figueirinhas apresenta-se como legítimo representante das forças políticas que disputavam o controle do Estado e da sociedade e que em breve seriam vitoriosas e permaneceriam hegemônicas até abril de 1975, com o fim do salazarismo e o início do processo de redemocratização do país.

\section{Outros Empreendimentos de Figueirinhas}

Como dito anteriormente, três anos após habilitar-se para o magistério primário, Figueirinhas fundou, em Oliveira de Frades, o Colégio Viriato, o qual seria transferido para a cidade de Viseu, seis anos depois. Entretanto, não foi essa primeira iniciativa de Figueirinhas, como proprietário de estabelecimentos de ensino, que chamou a nossa atenção.

No espaço do semanário pedagógico O Meu Jornal, reservado aos "anúncios e 
reclamos", um dos anúncios publicados chama a atenção, seja por ocupar quase dois terços de uma página, seja pelo conteúdo propriamente dito. Nele anunciava-se a abertura de um internato feminino na cidade do Porto. Tratava-se do Colégio de Santa Isabel, localizado na Rua de Santa Catarina, $\mathrm{n}^{\circ} 1.580$, junto à Praça Marquês de Pombal. O anúncio trazia uma fotografia da fachada do edifício. Nos anúncios sobre esse colégio, publicados nos números seguintes do jornal, duas outras fotografias foram acrescentadas à primeira: uma delas explorando o requinte da sala de jantar e, a outra, um detalhe do pátio interno: uma alameda arborizada a sugerir um ambiente bucólico e de muito recato. Na íntegra, o texto desse anúncio:

É o mais belo edifício dos colégios femininos de Portugal. Situado no ponto mais alto da cidade do Porto, isolado por quatro ruas: Santa Catarina, Rua Latino Coelho, Rua das Doze Casas, Rua Gil Vicente, o COLÉGIO DE SANTA ISABEL oferece vistas deslumbrantes da cidade, do mar, de Vila Nova de Gaia. Dormitórios excelentes, voltados ao Sul e Nascente para o parque, sala de jantar encantadora, aulas desafogadas, lindos salões, um parque admirável para recreio. O COLÉGIO DE SANTA ISABEL propõe-se ministrar às suas alunas uma educação moral, científica, literária e artística, quanto possível completa, nunca perdendo de vista a formação da verdadeira dona-de-casa.

O COLÉGIO DE SANTA ISABEL não admite alunas externas, o que dá superiores vantagens ao internato, sob todos os aspectos.

As línguas estrangeiras serão ensinadas praticamente por professoras das respectivas nacionalidades, sendo o corpo docente distinto $\mathrm{e}$ escrupulosamente selecionado.

Enviam-se programas a quem os requisitar. Toda a correspondência deve ser dirigida a Maria Pinto Figueirinhas. (O MEU JORNAL, Porto, p. 3, 24 set. 1916).

A menção a esse anúncio tem por objetivo destacar a recorrente iniciativa empresarial de Figueirinhas (e supostamente de seus familiares) no campo da educação escolar.

Conseguimos reunir poucas informações sobre Maria Pinto Figueirinhas, a quem toda a correspondência dos interessados em obter informações sobre o Colégio de Santa Isabel deveria ser dirigida. Sabemos que nasceu (18??) e faleceu (1926) na cidade do Porto, e que escreveu vários livros sobre literatura infantojuvenil, todos eles publicados entre 1905 e 1940 pelas seguintes editoras: Casa Editora de António Figueirinhas (sete livros), Livraria Editora Ferreira \& Oliveira (um livro), Companhia Portuguesa Editora (um livro) e Editora de Educação Nacional (seis livros, sendo um deles em coautoria com J. António Freitas e Maximiliano de Azevedo) (PATRIARCA, 2012, p. 356-357); na avaliação de Patriarca (2012, p. 164), são livros “[...] cuja temática e enredo assentam na exaltação das virtudes e na denúncia dos vícios, com especial apreço pela prática das boas ações, pelos valores do trabalho e da humanidade, da benevolência e da partilha". Sabemos, ainda, que foi autora de um manual escolar, intitulado Primeiro Livro de Leitura das Escolas Primárias, cuja $11^{\mathrm{a}}$ edição foi publicada pela Companhia Portuguesa Editora (NÓVOA; BANDEIRA, 2003). Não conseguimos saber, entretanto, se Maria Pinto Figueirinhas e António Figueirinhas eram parentes; a considerar os indícios acima apresentados, pensamos que sim.

A corroborar o espírito e a prática empreendedora da família Figueirinhas no campo da educação escolar, outra iniciativa de não somenos importância deve ser registrada. Além de editor, livreiro, proprietário de revistas, jornais e de estabelecimentos de ensino, 
Figueirinhas também foi proprietário de uma fábrica de móveis escolares, também ela anunciada e "reclamada" nas páginas de O Meu Jornal.

\section{Considerações Finais}

À luz das evidências reunidas neste texto, António Figueirinhas pode ser considerado um insofismável empresário da educação. Boa parte das matérias que levava ao conhecimento do seu público-leitor era convertida, tempos depois, em assunto e título de livros, geralmente de autores pertencentes à sua rede de relações.

Não foram poucos os artigos sobre livros e sobre o ensino calcado em livros publicados em O Meu Jornal. Naturalmente, era do interesse do proprietário do jornal que o professor não deixasse de fazer uso de livros escolares em sua prática de ensino, principalmente os editados por ele. Afinal, a expansão do ensino para a totalidade da população portuguesa de então era uma das principais bandeiras dos republicanos que queriam construir uma nova sociedade. Nesse sentido, a educação popular pôde ser vista como um grande negócio. António Figueirinhas é um dos representantes dessa visão. O uso que ele fez da imprensa especializada (em educação), criando periódicos e praticando o jornalismo como o fez, evidencia um homem de "visão empresarial". O jornal, para ser lido por seus assinantes - professores primários, basicamente - precisava "vender" assuntos de interesse do professorado, e ser barato. O Meu Jornal parece ter conseguido alcançar esse objetivo. A assinatura custava $1 \$ 00$ (um escudo) ${ }^{17}$ ao ano, e o número avulso era vendido a quatro centavos de escudo. Essas cifras parecem irrisórias, quando confrontadas com as de periódicos assemelhados editados no mesmo período. Os temas abordados no jornal eram, ao que tudo indica, do interesse do professorado. Além de trazer matérias de fácil leitura, discorria sobre temas atuais e procurava atualizar o professor sobre os seus direitos trabalhistas. Assim, por meio dessas estratégias, António Figueirinhas conseguia fazer propaganda dos livros que editava, fossem eles de sua própria autoria, ou não. Esse empresário da educação escolar soube representar muito bem esse papel.

Não se pode afirmar (por falta de evidências) ter sido António Figueirinhas um monarquista, posto não ter poupado críticas à República recém-instituída e aos republicanos, tanto os "históricos" quanto aqueles por ele denominados de "republicanos de última hora". Esse discurso crítico à República portuguesa do início do século XX pode ensejar outras compreensões do discurso republicano vitorioso, sobretudo no que diz respeito à educação escolar. Também não pode ser rotulado de fascista, igualmente por falta de evidências. É fato, entretanto, que ele se deslumbrou com as práticas escolares de uma Itália que vivia sob o regime fascista, como ele mesmo tornou público. Nas críticas que fez a Adolfo Lima, quando do episódio sobre os "livros escolares aprovados" pelo Ministério Público, expressou seu desconforto em relação às principais teses do movimento escolanovista, como o ensino laico, a escola racional, a educação integral e a escola única, todas elas defendidas, não apenas por Adolfo Lima, mas, também, por outros tantos educadores portugueses considerados progressistas, como Emílio Costa ${ }^{18}$ e César Porto, por exemplo.

Pode-se afirmar que António Figueirinhas, como empresário da educação, foi um personagem emblemático de uma sociedade (a sociedade portuguesa recém-saída de um milenar regime monárquico) que vivia intensamente as transformações pelas quais 
passava. A instituição escolar participava ativamente desse momento histórico, produzindo e sendo produzida ${ }^{19}$ por uma sociedade que se modernizava de forma bastante contraditória e observando um ritmo bastante moderado de modernização, se comparado ao ritmo verificado nas demais sociedades europeias de então.

\section{Referências}

BANDEIRA, Filomena. [Verbete] Emílio Costa. In: NÓVOA, António; BANDEIRA, Filomena. (coord. geral). A educação portuguesa: corpus documental (séculos XIXXX): dicionário de educadores portugueses. Lisboa: Edições Asa (versão digital), 2003.

CANDEIAS, António. [Verbete] Adolfo Lima. In: NÓVOA, António; BANDEIRA, Filomena. (coord. geral). A educação portuguesa: corpus documental (séculos XIXXX): dicionário de educadores portugueses. Lisboa: Edições Asa (versão digital), 2003.

. (dir. e coord.). Alfabetização e escola em Portugal nos séculos XIX e XX: os censos e as estatísticas. Lisboa: Fundação Calouste Gulbenkian, 2004.

CASTELO, Claudia. [Verbete] César Porto. In: NÓVOA, António; BANDEIRA, Filomena. (coord. geral). A educação portuguesa: corpus documental (séculos XIXXX): dicionário de educadores portugueses. Lisboa: Edições Asa (versão digital), 2003 a.

. [Verbete] Eusébio Ferreira de Queirós. In: NÓVOA, António; BANDEIRA, Filomena. (coord. geral). A educação portuguesa: corpus documental (séculos XIXXX): dicionário de educadores portugueses. Lisboa: Edições Asa (versão digital), 2003b.

CHARTIER, Roger. O mundo como representação. Estudos Avançados. São Paulo, n. 11 (5), p. 173-190, jan./abr. 1991.

FERNDANDES, Rogério. Tendências da política escolar e a escola para todos em Portugal na segunda metade do século XX. In: FERNANDES, Rogério; PINTASSILGO, Joaquim. (orgs.). A modernização pedagógica e a escola para todos na Europa do Sul no século XX. Lisboa: Grupo SPICAE, 2003. p. 9-26.

MAGALHÃES, Justino. A escola elementar e a leitura em Portugal. In: FERNANDES, Rogério.; PINTASSILGO, Joaquim. (orgs.). A modernização pedagógica e a escola para todos na Europa do Sul no século XX. Lisboa: Grupo SPICAE, 2003. p. 91-98.

NÓVOA, António. (dir.). A imprensa de educação e ensino: repertório analítico (séculos XIX-XX). Lisboa: Instituto de Inovação Educacional, 1993 (versão digital).

NÓVOA, António; BANDEIRA, Filomena. [Verbete] António Simões Ferreira Figueirinhas. In: A educação portuguesa: corpus documental (séculos XIX-XX): dicionário de educadores portugueses. Lisboa: Edições Asa (versão digital), 2003.

O MEU JORNAL. Semanário Pedagógico do professor e dos Amigos da Instrução. Porto: Imprensa Civilização, 1915-1917.

PATRIARCA, Raquel. O livro infantojuvenil em Portugal entre 1870 e 1940 - Uma perspectiva histórica. 2012. 422 f. Tese (Doutoramento em História)-Departamento de História e Estudos Políticos e Internacionais, Faculdade de Letras, Universidade do Porto, Porto, 2012. 
PETITAT, André. Produção da escola / Produção da sociedade: análise sócio-histórica de alguns momentos decisivos da evolução escolar no Ocidente. Porto Alegre: Artes Médicas, 1994.

PINTASSILGO, Joaquim; MOGARRO, Maria João. A ideia de escola para todos no pensamento pedagógico português. In: FERNANDES, Rogério; PINTASSILGO, Joaquim. (orgs.). A modernização pedagógica e a escola para todos na Europa do Sul no século XX. Lisboa: Grupo SPICAE, 2003. p. 51-71.

TEODORO, António. O Estado Novo e a educação. As mudanças invisíveis na sociedade portuguesa do pós-guerra e a expansão educativa. In: FERNANDES, Rogério; PINTASSILGO, Joaquim. (orgs.). A modernização pedagógica e a escola para todos na Europa do Sul no século XX. Lisboa: Grupo SPICAE, 2003. p. 27-50.

THOMPSON, Edward Palmer. A miséria da teoria ou um planetário de erros (uma crítica ao pensamento de Althusser. Rio de Janeiro: Zahar, 1981.

\section{Notas} ${ }^{1}$ Professor do Programa de Pós-Graduação Stricto Sensu em Educação da Universidade Católica de Santos -
UniSantos. Doutor em Educação: Filosofia e História da Educação pela Faculdade de Educação da
Universidade Estadual de Campinas - Unicamp, com estágio pós-doutoral em História da Educação na
Universidade de Lisboa. Contatos: luiz.barreira@ unisantos.br/ luizcarlosbarreira@gmail.com.

${ }^{2}$ Este trabalho foi apresentado no Simpósio Temático "História, Memória e Ensino de História: Diálogo entre Diferentes Saberes”, que integrou a programação do XXVI Simpósio Nacional de História, realizado em julho de 2011, na Universidade de São Paulo.

${ }^{3}$ Periódico da imprensa portuguesa de educação e ensino dos mais longevos, editado na cidade do Porto em três momentos: de 04/10/1896 a 02/04/1911, de 01/07/1912 a 20/08/1919 e de 23/02/1927 a 20/05/1976.

${ }^{4}$ Quando de nossa ida a Portugal, no segundo semestre de 2005, para realização de estágio pós-doutoral na Universidade de Lisboa (convênio CAPES-GRICES).

${ }^{5}$ Sobre o uso que aqui fazemos da expressão "lutas de representações", consultar Chartier (1991).

${ }^{6}$ De 11 de junho de 1905 a 02 de abril de 1911, Figueirinhas foi, com algumas interrupções, diretor e proprietário de Educação Nacional; de abril de 1911 a junho de 1912, e de agosto de 1919 a fevereiro de 1927, Educação Nacional deixou de circular; entre julho de 1912 e agosto de 1919, Figueirinhas não participou da gestão desse periódico, deixando de ser, inclusive, o seu proprietário; em 23 de fevereiro de 1927, depois de uma interrupção de oito anos, Educação Nacional teve o seu projeto original retomado sob os auspícios de António Figueirinhas, que seria o seu diretor e proprietário até 17 de janeiro de 1945, meses antes do seu falecimento (NÓVOA, 1993, referência 173).

7 Conforme notas biográficas de Cláudia Castelo (2003a), César Porto foi um dos impulsionadores da Educação Nova em Portugal. Formou-se em Antropologia, em Paris, e exerceu o magistério primário em várias escolas portuguesas. Maçom e republicano, César Porto iniciou sua vida política nas lides libertárias, tendo sido um assíduo colaborador do jornal A Batalha. Nasceu em Lisboa em 30 de novembro de 1873 e faleceu, também em Lisboa, em 25 de dezembro de 1944. Na Escola Oficina, foi professor de Português e Sociologia. Tempos depois, assumiu a direção pedagógica dessa mesma escola. Dentre outras atividades, compôs a comissão promotora da Liga de Ação Educativa, fez parte do conselho pedagógico da Universidade Popular Portuguesa e visitou a Rússia a convite da Federação Pan-Russa dos Trabalhadores de Ensino.

${ }^{8}$ Conforme as notas biográficas sobre Adolfo Lima, escritas por António Candeias (2003), o eminente educador português nasceu em Lisboa em 28 de maio de 1874 e faleceu, também em Lisboa, em 27 de novembro de 1943. Filho de pai português e de mãe brasileira, Adolfo Lima formou-se em Direito pela Universidade de Coimbra. Entre 1906/07 e 1914, foi professor de Sociologia e diretor pedagógico da Escola Oficina. Enquanto lá esteve, também dirigiu Educação, revista editada pela Sociedade Promotora de Escolas, também ela proprietária e fundadora da Escola Oficina. Depois de ter passado pela Escola Oficina, Adolfo 
Lima começou a lecionar no Liceu Pedro Nunes. Em fevereiro de 1918, assumiu a direção da Escola Normal Primária de Lisboa, permanecendo nessa função até maio de 1921. Esteve vinculado à Escola Normal, como professor, até 1933. A partir de então, assumiu a direção da Biblioteca-Museu do Ensino Primário, que era anexa à Escola Normal de Lisboa. No período em que esteve ligado à Escola Normal, dirigiu a revista Educação Social.

${ }^{9}$ As notas biográficas sobre Eusébio Gonçalves de Queirós, escritas por Claudia Castelo (2003b), informam que o redator de $\mathrm{O}$ Meu Jornal nasceu e morreu na cidade do Porto. Não precisam, entretanto, as datas de nascimento e de falecimento do biografado, informando, apenas, os anos de tais acontecimentos, quais sejam, 1870 e 1943. Queirós foi professor do ensino primário, secundário e comercial e inspetor escolar. Destacouse pela intensa colaboração na imprensa pedagógica do início do século XX (O Magistério Português, Educação Nacional, A Tribuna e $\mathrm{O}$ Meu Jornal, entre outros periódicos) e pela participação no associativismo docente (grêmios e montepios), destacadamente no período que abarca o final da Monarquia e o início da Primeira República. Foi autor de livros escolares (para o ensino da História, da Corografia e da Gramática, principalmente) e escreveu peças teatrais infantis, romances e poesias. Foi, ainda, um incentivador da festa escolar da árvore, por preocupar-se em fomentar na criança o amor e o respeito pela natureza e pela pátria.

${ }^{10}$ Nenhum dado biográfico sobre Rodrigues dos Santos foi localizado.

${ }^{11}$ Nenhum dado biográfico sobre José de Queirós foi localizado.

${ }^{12}$ Nenhum dado biográfico sobre Juliano Pereira foi localizado.

${ }^{13}$ Nenhum dado biográfico sobre Domingos de Sousa foi localizado.

${ }^{14}$ Nenhum dado biográfico sobre Hermínio Andrade foi localizado.

${ }^{15}$ Nenhum dado biográfico sobre João Paulo Freire foi localizado.

${ }^{16}$ Nenhum dado biográfico sobre Manuel de Melo foi localizado.

${ }^{17}$ O escudo foi criado em 22 de maio de 1911, cinco meses após a Proclamação da República portuguesa, por decreto do Governo Provisório. Nessa altura, 1\$00 (um escudo) correspondia a 1\$000 (mil réis, ou reais).

${ }^{18}$ Emílio Costa nasceu em 21 de fevereiro de 1877, na cidade de Portalegre, e faleceu em 17 de fevereiro de 1952, em Lisboa. Teve uma rápida passagem pela Escola Oficina $\mathrm{N}^{\circ}$ 1, de Lisboa, e publicou um único artigo na revista Educação Social, intitulado "Escola do Trabalho". De acordo com as notas biográficas de Filomena Bandeira (2003), Emílio Costa nasceu no seio de uma família burguesa liberal de Portalegre. Após sua formação inicial, entrou para o Liceu Mouzinho da Silveira em 1887, concluindo o ciclo secundário em 1894. Dois anos depois, instalou-se em Lisboa para frequentar o Instituto Industrial. Assim que chegou a Lisboa, em 1896, envolveu-se na vida acadêmica, que era fortemente politizada e dominada pelo republicanismo. Em 1897, subscreveu o Manifesto Acadêmico Republicano, esteve na fundação do Centro Acadêmico Republicano, entrou para a Maçonaria Acadêmica e para a Carbonária Portuguesa. Em 1899, também se matriculou no Curso Superior de Letras, mas não concluiu nenhum desses cursos. Em 1903, decidiu divagar pela Europa, percorrendo a França, a Bélgica e a Suíça. Foi um dos principais doutrinadores e divulgadores das ideias libertárias. No último ano em que perambulou pela Europa, mais especificamente pela França (1908), aproximou-se de uma comunidade pedagógica de vanguarda. Nesse momento, atuou como secretário pessoal de Ferrer. Colaborou na fundação da Liga Internacional para a Educação Racional da Infância e tentou organizar uma seção em Portugal. A experiência alcançada durante esse período forneceulhe o conhecimento dos núcleos anarquistas mais importantes do meio sindical internacional, assim como das suas estruturas organizativas e métodos de ação, além do estudo doutrinário.

${ }^{19}$ Corroboramos o entendimento que André Petitat (1994) tem das relações que as instituições sociais estabelecem entre si, produzindo-se mutuamente.

Recebido: julho-15 Aprovado: dezembro-15 